\title{
Green University Using Cloud Based Internet of Things Model for Energy Saving
}

\author{
Sunti Sopapradit ${ }^{1} \&$ Pallop Piriyasurawong ${ }^{2}$ \\ ${ }^{1}$ Faculty of Science and Technology, Southeast Bangkok College, Bangkok, Thailand \\ ${ }^{2}$ Faculty of Technical Education, King Mongkut's University of Technology North Bangkok, Thailand \\ Correspondence: Sunti Sopapradit, Faculty of Science and Technology, Southeast Bangkok College, Bangkok, \\ Thailand. E-mail: suntispp@gmail.com
}

Received: March 18, 2020

doi:10.5539/ies.v13n9p123
Accepted: April 25, $2020 \quad$ Online Published: August 28, 2020

URL: https://doi.org/10.5539/ies.v13n9p123

\begin{abstract}
The research was conducted to study and develop a Green University using Cloud based Internet of Things model for energy saving. The aims of this study were 1) to study and design 2) to evaluate a model of Green University using Cloud based Internet of Things for energy saving. There are two phases of the research method. The first phase included the model design: 1) to study, analyze, and synthesize the contents, 2) to develop a process model of Green University using Cloud based Internet of Things, 3) to present the constructed model, and 4) to conclude the results. The second phase is referred to an evaluation of the model. Nine experts from Green University's Electrical, Information Technology, and university management team were included in the research as sample group. Then, the data were analyzed by standard deviations and means. The model development process has 3 components that include 10 procedures. This model helps to energy saving. As the overall model was shown at a very good level, the experts agreed.
\end{abstract}

Keywords: green university, cloud computing, energy saving

\section{Introduction}

Energy is an important basic factor for the industry, agriculture, and education developments because energy is key to proceed with all kinds of works in order to comply with the convenient routines of human. Thus, world energy consumption has increased by approximately 7\% each year (Ministry of Energy, n.d.), and the rate expected to rise continuously in the future. However, some types of existing energy are limited such as energy from natural fuel. That is why it is necessary for everyone to conserve, and use energy sufficiently, especially the higher education level which is mandatory to launch the campaign to educate and encourage people to realize how valuable energy and environment are. The previously mentioned campaign then creates a policy and practices that are crucial for life and the academy's fellowship that are altogether called 'Green University' (Green-Campus Office, 2016).

Green University is posited to be a university that encourages, develops, restores, conserves, and integrates knowledge and activities that are related to natural resources, energy and environment conservation, self-reliance improvement on the basis of ecology and people's health balance, research and learning systems development, and different activities that use the Internet of Things: IoT in order to comply with the energy saving (Pibul Songkram Rajabhat University, 2013)

Internet of Things: IoT is the $21^{\text {st }}$ century technology that can communicate, command, and control the operation of electronic devices (Prapaporn, 2016) via an internet network system. Furthermore, IoT is a tool for data processing via radio frequency, sensor technology, smart technology and other kinds of technologies (Hua et al., 2014). After IoT is used, it is common that most processed data will be stored and analyzed on 'Cloud' (Pramanik et al., 2018).

Cloud Computing or so called 'Cloud' is a type of internet-based computing that uses a variety of existing resources on internet networks such as processing and storage. Computer users may use cloud computing via 'Internet Service Provider (ISP)' that supplies different services (Office of the National Economic and Social Development Board, 2011). The service provider provides resources for users who need that service, and pay the service fees according to their actual usage. Moreover, cloud computing specializes in the flexible expansion which is referred to the ability to adjust the size to meet the requirement of users, and the ability to allocate the 
resources. Cloud computing focuses on the ease of long distance usage on internet network as its basis. This means cloud users are not required to have technical knowledge for basic usage. Most of the cloud computing services are displayed as the application of a website that allows users to use it via the website's browser and store all the input data on servers (Akarim \& Noppadon, 2015).

According to the stated information, the researcher decided to develop a model of Green University using Cloud based Internet of Things model of energy saving to guide people to pursue 'Green University' efficiently. In addition, the proposed model framework was evaluated by experts to study whether the variables are appropriate for the model.

\subsection{Research Objectives}

The aims of this study were:

1) To study and design a model of Green University using Cloud based Internet of Things for energy saving, and

2) To evaluate a model of Green University using Cloud based Internet of Things for energy saving.

\subsection{Conceptual Framework}

This research's framework consists of two components. The mentioned components are: Green University, Cloud Computing and Internet of Things as shown in Figure 1.

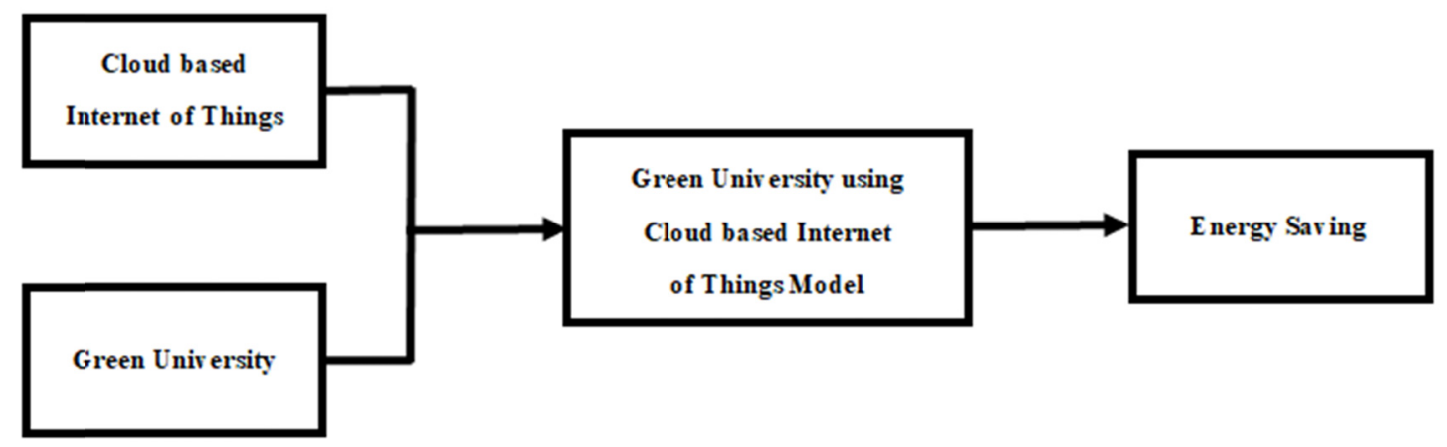

Figure 1. Concept framework

\subsection{Population}

The population of this study consisted of Green University's Electrical, Information Technology and university management team experts.

\subsection{Samples}

These experts were chosen by the method of purposive sampling of individuals who have at least five years' experience in relevant fields.

\subsection{Variables of this research}

1) The Green University using Cloud based Internet of Things model for energy saving model was independent variable.

2) The assessment of the model's suitability was the dependent variable.

\section{Research Methodology}

This research has 2 parts.

\subsection{The First Part}

The first part is the development of a model of Green University using Cloud based Internet of Things for energy saving. The processes are as follow:

1) To study, scrutinize, and combine previous research and documents related to the elements of the Green University (Big C Supermarket, 2019; PTT Public Company Limited, 2019; Hamzah et al., 2018; International alliance of research universities, 2016; Dave et al., 2013) Cloud Computing (Alsamhi, 2018, Ning et al., 2018, Dave et al., 2013) and Internet of Things (Moore \& Iyer, 2019; Alsamhi, 2018; Hamzah et 
al., 2018; Mu et al., 2015; Wang, 2014; Dave et al., 2013).

2) To develop a model of the Green University using Cloud based Internet of Things for energy saving by using collected data from relevant research and documents.

3) To present a model of the Green University using Cloud based Internet of Things for energy saving via in-depth interviews to experts and advisors for their consideration.

4) To create evaluating tools for the model suitable.

\subsection{The Second Part}

The second part of this study focuses on an evaluation of a model of Green University using Cloud based Internet of Things for energy saving, with methods as follows:

1) Presenting the developed model of Green University using Cloud based Internet of Things for energy saving to nine experts in the fields of Green University, Electrical, Information Technology and university management team.

2) Improving the design of the model base on the experts' suggestions.

3) Presenting the diagram with reports of this model.

4) Analyzing the model's results evaluation by using mean $(\overline{\mathrm{X}})$ and standard deviation (S.D.). A 5-point rating scale based on the Likert scale was used to design the evaluation form.

\section{Results}

There are 2 phases of this research's results.

\subsection{The First Phase}

This model is illustrated in Figure 2. The constructed model has 3 components with 10 procedures as follows:

Component 1. 'Input' which has 3 parts: 1) Energy saving policy for higher education level. 2) Stakeholders such as manager, university crew and student and 3) The standard of Green University towards energy saving.

Component 2. 'Process' which consists of 10 different considerate parts:

1) Appointing Green University's policy committee: The committee from individuals who have knowledge about 'Green University'. The policy committee included Managing Director (Chancellor or Deputy Chancellor), Dean of different departments, building's superintendent, technician, staff, and stakeholders who understand Green University.

2) Digging into the history of energy consumption in the past: The committee studied and searched for the university data about energy consumption statistics, location, basic construction, and budget in order to plan the policy.

3) Valuating the basic preparation of energy saving: The committee analyzed the potential of university's readiness towards basic energy saving.

4) Setting a policy and publicizing this campaign: The committee planned the execution policy that was divided into 3 range sections: short term, middle term, and long term. The committee also provided essential information and raises the awareness of university staff.

5) Appointing committee of the campaign: The committee made an action plan, and appointed a team to proceed and manage the campaign according to the instructed plan.

6) Targeting and planning for energy saving: The committee and staff jointly set goals, and planned for the objective plan and action plan of each energy saving project.

7) Carrying out the energy saving planned campaign: The committee and staff encouraged other people in the institution to work together on the plan of different projects or campaigns to promote the cause of saving energy.

8) Evaluating the process: The committee evaluated and followed up every step of the process according to the action plan.

9) Analyzing and continuous modifying: The committee reviewed and analyzed the step of action plan that could not be done according to the plan. They also had to renew self-assessment annually.

10) Executing the prototype: The committee appointed the institution staffs and team staffs to work on the successful campaign or project in order to build up the model and method to conserve other different types of 
energy.

These 2 mentioned components used technology suach as: sensor, embedded system, cloud computing3, and communication to operate in the process.

Component 3. Output is referred to 2 main elements as follows: 1. 'efficiency' that can be obtained from energy saving such as reducing the cost of electricity fees, and 2. 'effectiveness' that can be increased and created by energy saving methods and activities.

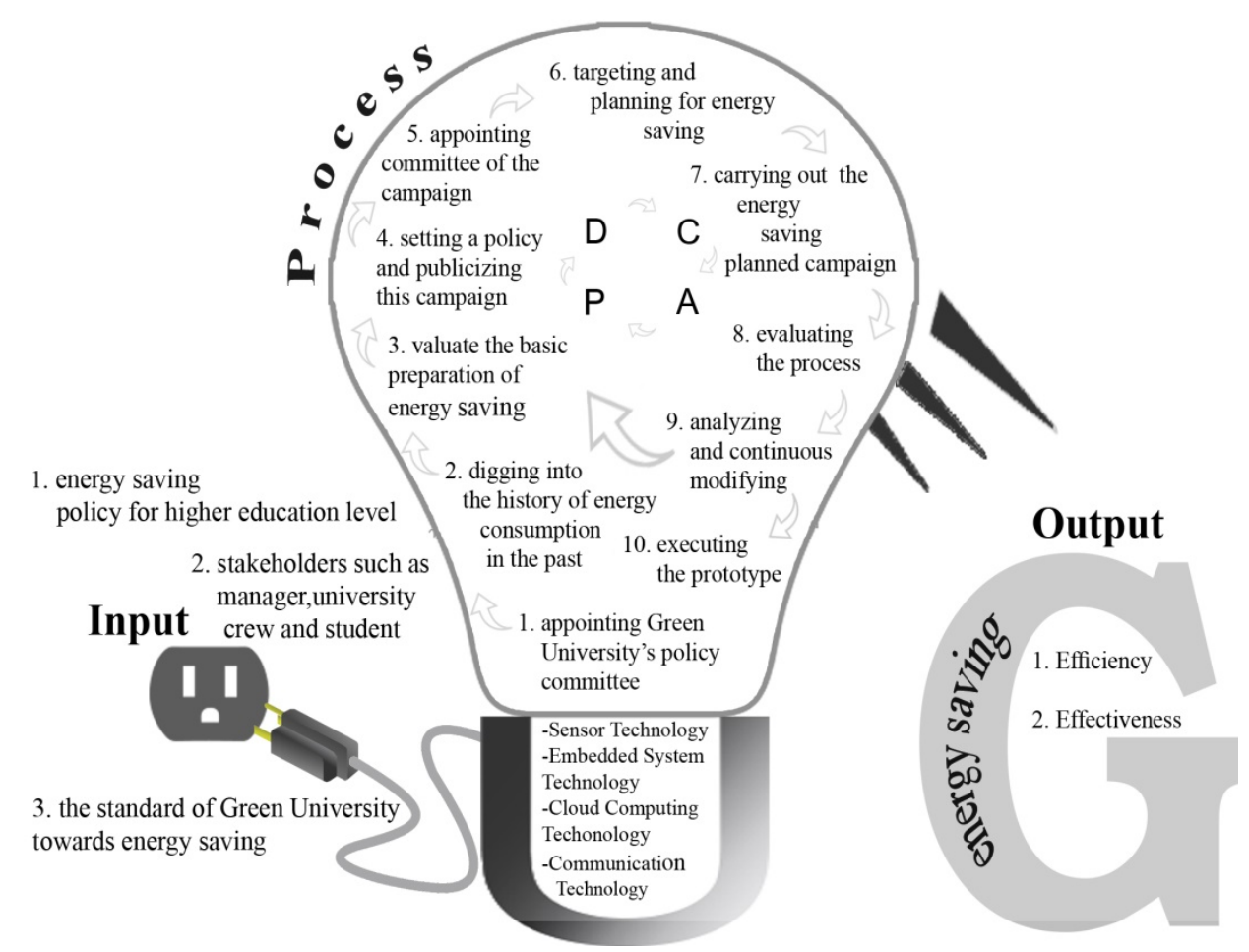

Figure 2. Green university using cloud based internet of things model for energy saving

\subsection{The Second Phase}

The model's appropriateness evaluation was done by nine experts as presented in Table 1. And, they agreed with the value of overall suitable on the list that had great results $(\bar{X}=4.58$, S.D. $=0.03)$. The appropriateness of a Green University using Cloud based Internet of Things could be utilized in the practical system was ranked as 'very good' $(\bar{X}=4.78$, S.D. $=0.44)$. As the overall, value of the components of a model of Green University using Cloud based Internet of Things could satisfy the needs, was completed. And, the function of the model was accurate to the aims of this research ranked as very good $(\bar{X}=4.67$, S.D. $=0.50)$. The relations between value of each component towards one another was ranked as very $\operatorname{good}(\bar{X}=4.56$, S.D. $=0.53)$, the sequence arrangement of components in a model of Green University using Cloud based Internet of Things was easy to understand and appropriate was ranked as very good $(\bar{X}=4.53$, S.D. $=0.53)$, and the system principles that were used as the basis to construct a Green University using Cloud based Internet of Things Model was also ranked as very good $(\bar{X}=4.53$, S.D. $=$ $0.53)$. 
Table 1. Results of appropriateness evaluation of a model of green university using cloud based internet of things model for energy saving

\begin{tabular}{|c|c|c|c|}
\hline \multirow[b]{2}{*}{ Evaluation Lists } & \multicolumn{2}{|c|}{ Results } & \multirow{2}{*}{$\begin{array}{l}\text { Appropriat } \\
\text { eness } \\
\text { Level }\end{array}$} \\
\hline & $\bar{X}$ & S.D. & \\
\hline $\begin{array}{l}\text { 1. The system principles that were used as the basis to construct a Green University using Cloud based Internet } \\
\text { of Things Model. }\end{array}$ & 4.56 & 0.53 & Very Good \\
\hline 2. The model's components were related to a Green University using Cloud based Internet of Things Model. & 4.46 & 0.50 & Good \\
\hline 3. The model's component sequences are clear and unceasing. & 4.44 & 0.50 & Good \\
\hline 4. Each component's relations towards one another. & 4.56 & 0.53 & Very Good \\
\hline $\begin{array}{l}\text { 5. The sequence arrangement of components in a model of Green University using Cloud based Internet of } \\
\text { Things was easy to understand and appropriate. }\end{array}$ & 4.56 & 0.53 & Very Good \\
\hline $\begin{array}{l}\text { 6. As the overall value of the components in a model of Green University using Cloud based Internet of Things } \\
\text { could satisfy the needs, it was completed. And, the function of the model was accurate to the aims of this } \\
\text { research. }\end{array}$ & 4.67 & 0.50 & Very Good \\
\hline $\begin{array}{l}\text { 7. A model of Green University using Cloud based Internet of Things could develop suitable energy saving } \\
\text { methods. }\end{array}$ & 4.56 & 0.53 & Very Good \\
\hline 8. A model of Green University using Cloud based Internet of Things could be utilized in the practical system. & 4.78 & 0.44 & Very Good \\
\hline Summary & 4.58 & 0.03 & Very Good \\
\hline
\end{tabular}

\section{Discussion}

The Model of Green University has developed using cloud-based and Internet of Things for Energy Conservation. The model evaluated by the value of overall suitable on the list that had great results $(\bar{X}=4.55, \mathrm{SD}=0.49)$. Wang's (2013) study, which implied that Green University was effective and beneficial for energy saving, had complied with the design development. Moreover, the Internet of Things is technology in the $21^{\text {st }}$ century that can support life, communicate, command, and control the operation of electronic devices (Prapaporn, 2016) via an internet network system that was relevant to Sharma and Suryakanthi (2016). In addition, the Internet of Things can be shared with cloud computing which a system for storing data sent from sensors through network Internet and process data by processing data and displayed as the application of a website that allows users to use it via the website's browser and store all the input data on servers (Akarim \& Noppadon, 2015; Sathaporn \& Namon, 2015) to control the energy consumption.

\section{References}

Akarim, B., \& Noppadon, K. (2015). What is Cloud Computing? Retrieved from http://lib3.dss.go.th/fulltext/dss_knowledge/bsti-6-2558-cloud.pdf

Alsamhi, S., Ma, O., Ansari, M. S., \& Meng, Q. (2018). Greening internet of things for smart everything with a green-environment life: A survey and future prospects. Retrieved from https://arxiv.org/ftp/arxiv/papers/1805/1805.00844.pdf

Big C Supermarket. (2019). Energy management system and monitoring the energy management system for the year 2019. Retrieved from http://www.iecm.co.th/ongoing_en_bigc.html

Dave, M., Gou, Z., Prasad, D., \& Li, F. (2014). Greening Universities Toolkit V2.0: Transforming Universities into Green and Sustainable Campuses: A Toolkit for Implementers-Advance Copy.

Green-Campus Office. (2016). Smarter Sustainable Campus Communities: A Guide for Campuses Embarking on the Green-Campus Programme.

Hamzah, R. Y., Alnaser, N. W., \& Alnaser, W. E. (2018). Accelerating the transformation to a green university: University of Bahrain experience. In E3S Web of Conferences (Vol. 48, p. 06002). EDP Sciences. https://doi.org/10.1051/e3sconf/20184806002

Hua, L., Junguo, Z., \& Fantao, L. (2014). Internet of things technology and its applications in smart grid. TELKOMNIKA Indonesian Journal of Electrical Engineering, 12(2), 940-946.

International alliance of research universities. (2016). IARU Green Guide for Universities-Pathway Towards Sustainability.

Ministry of Energy (n.d.). Energy Conservation. Retrieved from http://thailandenergyeducation.com/assets/media/A006.pdf 
Moore, T., \& Iyer-Raniga, U. (2019). Reflections of a green university building: from design to occupation. Facilities, 37(3), 122-140. https://doi.org/10.1108/F-11-2017-0108

Mu, R., Liu, P., Song, Y., Cao, D., Zhan, L., Zuo, J., ... Yuan, X. (2015). Theory and Practice of Sustainability in Higher Education-From the Perspective of Green University. In 2015 Asia-Pacific Energy Equipment Engineering Research Conference. Atlantis Press. https://doi.org/10.2991/ap3er-15.2015.115

Ning, Z., Kong, X., Xia, F., Hou, W., \& Wang, X. (2018). Green and sustainable cloud of things: Enabling $\begin{array}{lllll}\text { collaborative edge computing. IEEE Communications Magazine, } & \text { 57(1), } & \text { 72-78. }\end{array}$ https://doi.org/10.1109/MCOM.2018.1700895

Office of the National Economic and Social Development Board. (2011). Summary, The Eleventh National Economic and Social Development Plan (2012-2016). Retrieved from http://www.nesdb.go.th/Portals/0/news/plan/p11/SummaryPlan11_En g.pdf

Pibul Songkram Rajabhat University. (2013). Logo Green University Contest. Retrieved from http://www.psru.ac.th/pdf/logo_contest.pdf

Pramanik, P. K. D., Pal, S., Brahmachari, A., \& Choudhury, P. (2018). Processing IoT Data: From Cloud to Fog-It's Time to Be Down to Earth. In Applications of Security, Mobile, Analytic, and Cloud (SMAC) Technologies for Effective Information Processing and Management (pp. 124-148). IGI Global. https://doi.org/10.4018/978-1-5225-4044-1.ch007

Prapaporn, K. (2016). Internet of Things: Current Technology Trends for Future. EAU Heritage Journal: Science and Technology, 10(1), 29-36.

PTT Public Company Limited. (2016). QSHE Management System. Retrieved from http://www.pttplc.com/th/Sustainability/Environment/Stewardship/Pages/Standards.aspx

Sathaporn, Y., \& Namon, J. (2015). Development of Collaborative Learning with Problem-Based Process Learning via Virtual Classroom on Cloud Technology to Enhance Information and Communication Technology Literacy of Undergraduate Students in the 21st Century. The Proceedings of International e-Learning Conference 2015 (pp. 277-281).

Sharma, K., \& Suryakanthi, T. (2016). Smart System: IoT for University. Proceedings of the 2015 International Conference on Green Computing and Internet of Things, ICGCIoT 2015 (pp. 1586-1593). https://doi.org/10.1109/ICGCIoT.2015.7380720

Wang, H. (2013). Toward a Green Campus with the Internet of Things-the Application of Lab Management. Proceedings of the World Congress on Engineering 2013 Vol II, WCE 2013, July 3-5, 2013, London, UK.

Wang, H. I. (2014). Constructing the green campus within the internet of things architecture. International Journal of Distributed Sensor Networks, 10(3), 804627. https://doi.org/10.1155/2014/804627

\section{Copyrights}

Copyright for this article is retained by the author(s), with first publication rights granted to the journal.

This is an open-access article distributed under the terms and conditions of the Creative Commons Attribution license (http://creativecommons.org/licenses/by/4.0/). 